some human dissection but had not done any with his own hands and had attended some university exercises, probably both lectures and disputations, conducted by Glisson. He had probably read the Aphorisms of Hippocrates, of which Ralph Winterton, Glisson's predecessor as professor of physic, had edited a convenient edition with translations of each aphorism into Greek and Latin verse, and from some passages in his writings he seems to have also read the Hippocratic treatises on air, water, and situation as well as the epidemics. He had also some reading in Galen. He could write and speak Latin. After taking his M.B. degree he continued his anatomical studies and worked practically at zoology, botany, chemistry, and pharmacology, and at medicine, parts of surgery, and morbid anatomy. He learned French and Italian and could speak a little Greek. He used every opportunity of conversing with learned men, such as Swammerdam the zoologist, Glauber the chemist, and Lambecius the bibliographer. He had read widely-"Purchas, his Pilgrims," the travels of de la Mantinière in the Arctic regions, Raleigh's "History of the World," Ashmole's "Order of the Garter," and the Duchess of Newcastle's "New Blazing World." His father advised him to study Cicero and not to read much of Lucretius. "Quotations may be taken from it," says Sir Thomas Browne, but " otherwise $I$ do not much recommend the reading or studying of it, there being divers impieties in it, and 'tis no credit to be punctually versed in it; it containeth the Epicurean natural philosophy." Besides his university examination. which was a kind of disputation, Edward Browne was no doubt examined in this College for admission as a candidate in 1668 after he had been engaged in medical studies for about ten years. He took his M.D. degree at Oxford in 1667, when he had studied nine years, and in his own university in 1670. This degree was probably given on proof of study in the faculty. It was chiefly in less regulated periods and work that this course of education differed from that of a physician in our time. There were as yet no organised schools of medicine in England and except in this College there was no thorough examination of candidates.

The study of history is most worth pursuing when the consideration of the past can be made useful to us in the present. The lesson, "Ars longa, vita brevis," is plain enough wherever we contemplate the attempts of men to learn and to teach medicine. Further than this, we may learn that it is only subjects thoroughly learned that are of value, and learned so that the student can feel that he has sought out things for himself and is not resting on the dicta of a teacher.

Last, we may conclude that medicine in itself, with its essential preliminary, anatomy, contains sufficient opportunities of training in every form of observation and of logical deduction from what is observed and, that for the rest, a mind which has been opened by a sound literary education is that best adapted to follow the lifelong study of medicine which is the duty of every physician. These are the conclusions to which I have been led by a study of the history of the education of physicians in London from the time of John Mirfeld to that of Edward Browne, from the Middle Ages to the time when the methods of study which we now follow began to be used.

\section{ON TRAUMATISM AS AN EXCITING CAUSE OF ACUTE APPENDICITIS ; WITH ILLUSTRATIVE CASES ${ }^{1}$}

By F. A. SOUTHAM, M.B. OxoN., F.R.O.S. ENG.,

SURGEON TO THE MANCHESTER ROYAL INFIRMARY; PROFESSOR OF CLINICAL SURGERY, UNIVERSITY OF MANCHESTER.

AtTention has recently been directed to the fact that under certain conditions traumatism may act as an exciting cause in the production of an attack of acute appendicitis and the matter is one of considerable interest not only from a clinical but also from a medico-legal point of view.

The question of cause and effect when appendicitis develops after an injury may involve important issues; for example, as regards the liability of accident insurance companies ; or, again, in cases where an attack of appendicitis

1 A communication delivered before the Manchester Medical Society on Nov. 1st, 1905. is followed by a fatal result and there is a history of an antecedent injury due to personal violence. In these circum. stances it is probable that the appendix was previously in an unhealthy or abnormal condition, for it is difficult to explain how violence applied to the abdomen could set up inflammation in the appendix unless this was the case. This view is supported by statistics, for in 50 cases collected from various sources by Kelly and Hurdon, ${ }^{2}$ where appendicitis followed an injury, there was definite evidence that an abnormal condition of the appendix had pre-existed in 40 instances (80 per cent.). The commonest was the presence of a fæcal concretion, this complication having been present in no less than 30 of the 40 cases ( 75 per cent.).

It is a well-recognised fact that deposits of inspissated fæcal matter or even calcareous concretions may be present in the appendix for a considerable time without causing any symptoms, for they are frequently found in operations for acute suppurative appendicitis and also at necropsies where previously there had been no indications whatever of their existence. If violence is applied to the abdomen over the region of an appendix which contains a frcal concretion it can readily be understood that the wall of the appendix at this spot, probably already somewhat damaged by the presence of the concretion, then becomes so injured that it suddenly ruptures or an attack of acute inflammation is set up, which may quickly terminate in ulceration and perforation. It is also possible that an appendix which is com. pletely stenosed at some point in its course and distended beyond with a mucoid or muco-purulent fluid-a condition which is not at all uncommon-may suddenly rupture as the result of violence applied to the abdomen and its contents become extravasated into the peritoneal cavity.

The following case is an illustration of the fact that a direct injury may excite an attack of acute suppurative appendicitis when a concretion is present.

CAsE 1.-A boy, aged nine years, with no previous history of any symptoms of appendicitis, was struck on the abdomen by some boys. The following day he complained of pain in the right iliac fossa and was confined to bed. On the second day he vomited continuously. On the fourth day he was admitted into the Manchester Royal Infirmary. His temperature was $100^{\circ} \mathrm{F}$., the pulse was 120 , and there was well-marked evidence of general peritonitis. 'The abdomen was opened shortly after admission and the appendix, which was inflamed and almost perforated at one spot, contained a fæcal concretion; there were numerous recent adhesions round the appendix and pus was diffused throughout the peritoneal cavity. Death took place about 12 hours after the operation. An inquest was held and the jury returned a verdict of " Accidental death."

In the following case, though the appendix was not seen and a concretion was not found, the condition was probably the same as in the preceding.

CASE 2.-A boy, aged seven years, who had previously enjoyed good health, while at play one morning fell upon his abdomen. He returned home complaining of abdominal pain which became much worse towards evening. Symptoms of general peritonitis developed, the temperature rising to $104^{\circ} \mathrm{F}$., and the pulse becoming very rapid. When seen in consultation on the third day the abdomen was extremely tender and so distended that it was impossible to make out. any swelling in the region of the appendix. The usual incision was at once made over the appendix and a large quantity of extremely foul pus was evacuated from the general peritoneal cavity. The appendix was not seen and the boy's condition being too grave to permit of any search being made for it the peritoneal cavity was merely washed out and drained. Contrary to expectation the boy made a good recovery from the operation and at the end of a month the wound was healed.

The following case differs from those described in the fact that the attack of appendicitis subsided without suppuration.

CASE 3.-A boy, aged 12 years, with no previous history of any symptom of appendicitis, was about to dive into a swimming bath when he was suddenly pushed in by a playmate so that he fell flat upon his abdomen, which forcibly struck the water. He was immediately seized with abdo. minal pain, most marked on the right side and so severe that he was obliged to leave the bath and at once return home. The following day he remained in the house, feeling unwell, and he was afterwards confined to bed, frequently 
vomiting, until his admission into the Manchester Royal Infirmary on the fourth day. When admitted his temperature was $101 \cdot 2^{\circ} \mathrm{F}$. and his pulse was 84 . The abdomen was somewhat distended, with general tenderness and resistance, most marked on the right side. Above the outer part of Poupart's ligament a distinct induration could be felt. In the course of three or four days the general distension and tenderness subsided under the application of belladonna and fomentations, and the temperature became normal. The induration above Poupart's ligament also gradually disappeared but a distinct thickening remained in the situation of the appendix and could still be detected at the time of his discharge three weeks subsequently, when he was sent to the convalescent home in the country. He came to show himself about a month later and the region of the appendix was then quite free from any swelling. Up to the present time, four months subsequently, there has been no further trouble.

It is also probable that without the application of any direct violence traumatism may excite an attack of appendicitis in another manner-e.g., a severe strain, by causing a sudden and forcible contraction of the abdominal muscles, may separate or break down adhesion between the appendix and the abdominal wall, causing an extravasation of blood either into or around the appendix, or possibly producing a rupture of its wall and allowing its contents to escape. Kelly and Hurdon state that in ten cases of appendicitis following an injury, where no concretion was found, there were evidences of old adhesions in seven. The following case probably belongs to this class, it being an established fact that mild attacks of appendicitis are often followed by the formation of firm adhesions between the appendix and adjacent structures. Statistics also show that adhesions are frequently found at necropsies where there has been no history of any attacks of appendicitis occurring during life.

Case 4.-A boy, aged 15 years, who in the preceding nine months had suffered from two mild attacks of abdominal pain and also from occasional slight "bilious" attacks, whilst out fishing strained himself in jumping across a stream and was at once seized with severe pain in the abdomen. The pain continued and in the evening he complained of feeling unwell. Symptoms of acute appendicitis developed and when seen in consultation later in the evening of the third day he presented typical symptoms of general peritonitis. The temperature was $101^{\circ} \mathrm{F}$. and the pulse was 130. There was general distension of the abdomen with dulness in each flank; over the region of the appendix there was slight increase of dulness with more resistance than on the opposite side. On the following morning the abdomen was opened and was found to be full of pus. The boy's condition was too serious to allow of any search being made for the appendix and no concretion was seen. Death took place about 12 hours after the operation. No necropsy was made.

Manchester.

\section{ON THE MULTIPLICITY OF COMPLE-} MENTS IN BACTERIOLYTIC SERA.

\author{
By W. H. C. FORSTER, M.B., C.M. Edin., \\ D.P.H. CANTAB. \\ CAPTAIN, I.M.S. \\ (Erom the Laboratory of the Pasteur Institute of India, \\ Kasauli.)
}

OF recent years most of the leaders of science have turned to bæmolysis in vitro for the purpose of ascertaining the general truths underlying lysogenic action. And wbilst it will be readily admitted that this indirect method at present offers the best possibilities of obtaining firm foothold for an attack on the problem of bacteriolysis, yet none the less the ultimate solution of this latter problem will only be cbtained by testing directly those general principles that may have been obtained by indirect methods. Further, for those who are not prepared to admit that the laws of hæmolysis and bacteriolysis are identical until they have been proved to be so, any direct attempt to solve the problem of bacteriolysis has this great advantage that results so obtained can only be invalidated on the grounds of faulty technique, erroneous observations, conceptions, or conclusions. Results so obtained cannot, however, be discredited on the ground of their incompatibility with re:ults obtained by indirect methods such as hæmolysis.

The literature on the subject of immunity has now attained to such vast proportions that any attempt at a critical résume would be quite out of place in a commonication of this nature. For the purposes of this paper, however, a very brief sketch will suffice. The $\mathrm{kr}$ sent state of our knowledge with regard to bacteriolysis was summarised as follows in the presidential address ${ }^{1}$ to the Section of Pathology at the Oxford meeting of the British Medical Association in 1904

We must recognise that it is limited to the statement that the killing of the bacteria is associated with the presence in the serum of an immune animal of two substances, one thermolabile (complement).... and the other thermostabile (immune body)...... There is this further fact that we are only certain of the specificity of the immune body-that is, we know that immune body will only act deleteriously on the protoplasm which stimulated its genesis. We cannot make a similar statement regarding complement.

If this statement be enlarged so as to include normal sera it will represent fairly accurately the state of our knowledge at the present day. With regard to the complement, it may be briefly stated that as the result of different conceptions as to the nature of lysogenic action there are two great schools of thought, one of which holds that there are at most not more than two complements, one being concerned in the 1ysis of bacteria and the other in the lysis of cells generally. The other school maintains that there are many different complements differing in their relations to the various amboceptors. The supporters of the pluralistic doctrine, working on the principle that identical chemical substances should give identical results with the same reagent, have employed the methods of differential heating, differential filtration, selective absorption, the use of anticomplements-natural and artificial-treatment with neutral substances, such as silica, digestion with ferments as papain, and treatment with alkalies, \&c., to prove their contention. The result of their labours has been to give a commanding position to the doctrine of the multiplicity of complements in hæmolytic sera. With regard to bacteriolytic sera, it was shown by Wright and Windsor, ${ }^{2}$ that if to a serum normally bactericidal for the bacillus typhosus a sterilised typhoid or cholera culture be added, the antibactericidal effect which is in each case obtained is obtained indifferently with either variety of sterilised culture. These observers argued from this that either the bactericidal substance in the serum which kills the typhoid bacillus is one and the same substance which kills the cholera vibrio, or alternatively that the bactericidal substance which kills the cholera vibrio possesses an element in common with the bactericidal substance which kills the typhoid bacillus. As the result of further experiments they concluded "that the bactericidal effects of a serum, at any rate in the case of a serum derived from the immunised animal, is achieved by the coöperation of two bactericidal elements, one of these being a chemical agent which exerts an action on more than one species of micro-organism, and the other a chemical agent which is specific for each particular species of microorganism." Longcope, ${ }^{3}$ working in the Ayer Clinical Laboratory, Pennsylvania Hospital, came to a very different conclusion. The method of this observer was to estimate the amount of unheated human serum necessary to reactivate one cubic centimetre of heated human serum for bacillus typhosus and bacillus coli respectively, standard quantities of emulsified agar cultures of these two organisms being used for the test. In the case of normal persons it was found that one-twentieth of a cubic centimetre of unheated serum was sufficient to re-activate one cubic centimetre of heated serum for a standard quantity of a typhoid emulsion. For the same quantity of the coli emulsion six-tenths of a cubic centimetre of unheated serum were necessary to reactivate one cubic centimetre of heated serum. In the case of the blood of persons suffering from typhoid fever it was found that the re-activating power of the serum was greatly diminished for typhoid bacilli and not for colon bacilli. The re-activating power of the sera of these typhoid patients was also tried against bacillus paracoli and bacillus dysenteriæ, and it was found that the sera showed a decreased reactivating power for typhoid bacilli alone. From this Longcope inferred the existence of a specific typhoid complement and concludes from his work that human blood

$$
\begin{aligned}
& 1 \text { Brit. Med. Jour., Sept. 7th, } 1904 . \\
& 2 \text { Journal of Hygiene, October, } 1902 .
\end{aligned}
$$$$
3 \text { Ibid., January, } 1903 .
$$ 